\title{
PEMETAAN TEMPAT PENAMPUNGAN SAMPAH (TPS) ILEGAL MENGGUNAKAN GEOGRAPHIC INFORMATION SYSTEM (GIS) DI WILAYAH KECAMATAN MATARAM KOTA MATARAM Mapping Illegal Solid Waste Disposal (TPS) Using Geographic Information System (GIS) In Mataram District Area, Mataram City
}

\author{
Erlan Siswandi ${ }^{1}$, Wahyudin ${ }^{2}$ \\ ${ }^{1,2}$ Program Studi Teknik Lingkungan, Sekolah Tinggi Teknik Lingkungan Mataram, Indonesia \\ Email Korespondensi: wahyudin.mts@gmail.com
}

\section{DOI:}

Abstract - The purpose of this study is to determine the distribution of illegal waste collection points (TPS) and their volume, as well as the influence of geophysical factors, anthropogenic factors and population factors on the distribution of illegal waste disposal sites (TPS). This research is a descriptive study which is strengthened by the results of Illegal TPS mapping based on Global Positioning System (GPS) data using Geographic Information System (GIS). Analysis of the data used is descriptive analysis and is presented in the form of output in the form of maps and data tabulations.

The results showed that the spread of locations from 43 Illegal TPS was almost evenly distributed in 9 sub-districts in Mataram District. Characteristics of Illegal TPS in terms of volume, distance from the river, type of land use, type of road occupied, and population density. The largest volume of Illegal TPS obtained was $36 \mathrm{m3}$, the location of Illegal TPS was less than $15 \mathrm{~m}$ from the river at $60.46 \%$ and was on the environmental road at $58.14 \%$. While population density cannot be the main factor related to its influence on the number of illegal polling stations in Mataram District. Thus the existence of the Illegal TPS has the potential to pollute the environment because it is close to the river and in a residential environment.

Keywords: solid waste, illegal TPS, mapping, GIS

\begin{abstract}
Abstrak - Tujuan penelitian ini yaitu untuk mengetahui sebaran titik-titik Tempat Penampungan Sampah (TPS) ilegal dan volumenya, serta pengaruh faktor geofisik, faktor antropogenik dan faktor kependudukan terhadap sebaran Tempat Penampungan Sampah (TPS) ilegal. Penelitian ini merupakan penelitian deskriptif yang diperkuat dengan hasil pemetaan TPS Ilegal berdasarkan data Global Positioning System (GPS) dengan menggunakan Geographic Information System (GIS). Analisis data yang digunakan yaitu analisis deskriptif dan disajikan dalam bentuk output berupa peta serta tabulasi data.

Hasil penelitian menunjukkan bahwa penyebaran lokasi dari 43 TPS Ilegal hampir merata di 9 kelurahan di Kecamatan Mataram. Karakteristik TPS Ilegal ditinjau dari volume, jarak dengan sungai, jenis penggunaan lahan, jenis jalan yang ditempati, dan kepadatan penduduk. Volume TPS Ilegal terbesar yang diperoleh yaitu sebesar $36 \mathrm{~m}^{3}$, lokasi TPS Ilegal berjarak kurang dari $15 \mathrm{~m}$ dari sungai sebesar 60,46\% dan berada di jalan lingkungan yakni sebesar 58,14\%. Sedangkan kepadatan penduduk tidak dapat dijadikan faktor utama terkait pengaruhnya terhadap jumlah titik TPS ilegal di Kecamatan Mataram. Dengan demikian keberadaan TPS Ilegal tersebut sangat berpotensi mencemari lingkungan karena berada dekat dengan sungai dan berada di lingkungan permukiman.
\end{abstract}

Kata kunci: sampah, TPS ilegal, pemetaan, SIG 


\section{PENDAHULUAN}

Sampah merupakan permasalahan yang harus segera diselesaikan di Negara ini karena dapat menyebabkan bencana alam, sumber penyakit, bau tak sedap, dan pemandangan yang buruk. Permasalahan yang mendasar di masyarakat adalah kebiasaan masyarakat yang cenderung membuang sampah sembarangan tanpa memikirkan dampaknya bagi lingkungan maupun kesehatan masyarakat itu sendiri. Kebiasaan ini menyebabkan terbentuknya timbulan sampah di berbagai tempat di sekitar kehidupan masyarakat, lebih-lebih di daerah perkotaan seperti Kecamatan Mataram Kota Mataram dengan tingginya jumlah penduduk dan aktivitas perekonomian yang padat.

Penampungan sampah yang tidak pada tempatnya yang sudah disediakan oleh pemerintah memunculkan adanya Tempat Penampungan Sampah (TPS) ilegal. Padahal peraturan tentang larangan membuang sampah di luar lokasi penampungan telah ditetapkan dalam Peraturan Daerah Kota Mataram Nomor 10 Tahun 2008.

Masalah lingkungan yang disebabkan oleh sampah dapat dimulai dari sumber sampah, dimana penghasil sampah lebih menyukai membuang sampah di tempat yang tidak jauh dari tempat tinggalnya, baik di pekarangan sekitar, ke saluran air maupun membakarnya langsung, sehingga mencemari lingkungan sekitarnya. Dampak dari penampungan sampah tidak pada tempatnya telah diketahui dapat menimbulkan kerusakan lingkungan yang parah, terutama di sekitar tempat penampungan ilegal tersebut. Yang sering terjadi dalam proses pembuangan sampah ialah pencemaran tanah dan air tanah, karena sampah tidak dikelola dengan baik dan benar. Selain itu, dampak dari pengelolaan sampah yang tidak tepat tersebut, masalah estetika lingkungan, timbulnya bau, serta timbulnya dampak negatif terhadap kesehatan akan muncul, selain itu juga dapat mengganggu kelestarian fungsi lingkungan (Rochman, dkk. 2012).

Peta adalah informasi (spasial) mengenai lingkungan. Kemudian pemetaan adalah suatu proses penyajian informasi muka bumi yang fakta (dunia nyata), baik bentuk permukaan buminya maupun sumbu alamnya, berdasarkan skala peta, sistem proyeksi peta, serta symbol-simbol dari unsur muka bumi yang disajikan (Jatmiko, 2011).

Tujuan utama pemetaan adalah untuk menyediakan deskripsi dari suatu fenomena geografis, informasi spasial dan non-spasial, informasi tentang jenis fitur, titik, garis, dan polygon (Indarto, 2010).

Dalam penelitian ini, pemetaan dilakukan menggunakan Geographic Information System (GIS) atau dalam Bahasa Indonesia disebut Sistem Informasi Geografis (SIG). GIS menurut ESRI (Environmental System Research Institute, 1996) yang dikutip oleh Riyanto (2010), "Geographic Information System (GIS) adalah kumpulan yang terorganisir dari perangkat keras komputer, perangkat lunak, data geografis, metode, dan personil yang dirancang secara efisien untuk memperoleh, menyimpan, memperbaharui, memanipulasi, menganalisis, dan menampilkan semua bentuk informasi yang bereferensi geografis".

Geographic Information System (GIS) merupakan sistem informasi berbasis komputer digunakan untuk menyajikan secara digital dan menganalisis penampakan geografis yang ada dan kejadian di permukaan bumi (Supriadi dan Nasution, 2007).

Pemanfaatan sistem informasi geografis (SIG) sebagai salah satu teknologi, dapat memberikan gambaran secara vicinal secara spasial maupun nonspasial suatu objek. Teknologi dapat mempermudah akses informasi salah satunya dengan menggunakan dua sistem yaitu sistem informasi geografis dan sistem pendukung keputusan, tata letak objek berbasis peta (Ni Ketut Pradani Gayatri S, Githa, Dwi Putra, 2018).

Berdasarkan permasalahan yang ada tersebut, maka perlu adanya suatu pemetaan lokasi penampungan sampah illegal di wilayah Kecamatan Mataram Kota Mataram sebagai upaya dalam mengawasi pertumbuhan TPS ilegal agar tidak memunculkan TPS ilegal lainnya di kemudian hari yang dapat membahayakan lingkungan dan keberlangsungan hidup masyarakat.

\section{METODE DAN DATA}

Penelitian ini akan dilaksanakan di wilayah Kecamatan Mataram Kota Mataram. Wilayah penelitian dibatasi oleh batas administrasi masing-masing kecamatan. Peta Rencana Tata Ruang Kecamatan Mataram digunakan sebagai dasar dalam penentuan wilayah sensus TPS ilegal di Kecamatan Mataram. Penelitian ini hanya akan mengindentifikasi titik-titik TPS ilegal di wilayah Kecamatan Mataram Kota Mataram yaitu Kelurahan Punia, Kelurahan Pagesangan Timur, 
Kelurahan Pagesangan Barat, Kelurahan Pagesangan, Kelurahan Pagutan Barat, Kelurahan Pagutan, Kelurahan Pagutan Timur, Kelurahan Pejanggik, Kelurahan Mataram Timur.

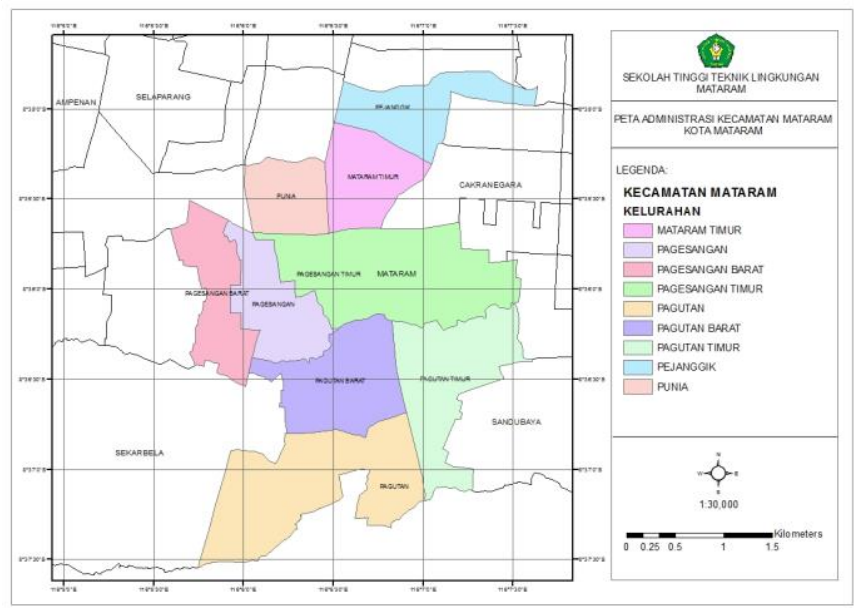

Gambar 1. Peta Administrasi Kecamatan Mataram Kota Mataram (Sumber: peneliti, 2019)

Penelitian ini merupakan penelitian deskriptif yang diperkuat dengan hasil pemetaan TPS Ilegal di wilayah Kecamatan Mataram Kota Mataram berdasarkan data Global Positioning System (GPS) dengan menggunakan Geographic Information System (GIS). Populasi yang digunakan dalam penelitian ini adalah seluruh TPS ilegal yang terdapat di wilayah Kecamatan Mataram sesuai dengan kriteria yang telah ditentukan. Teknik pengambilan sampel yang digunakan yaitu teknik totality sampling yaitu semua lokasi diambil sebagai sampel. Analisis data yang digunakan yaitu analisis deskriptif dan disajikan dalam bentuk output berupa peta serta tabulasi data. Adapun tahapan yang dilalui dalam pemetaan ini yaitu a) pembuatan peta dasar, meliputi mencari data shapefile di Badan Informasi Geospasial dan membuat peta dasar daerah yang diteliti. b) Pemetaan di lapangan, meliputi persiapan alat GPS Garmin 60 CSx, meteran, APD, alat tulis, kamera dan kendaraan, kemudian melakukan survei sesuai batas wilayah, perekaman jejak rute survey, ploting titik-titik TPS ilegal serta mengukur volume sampah, dan observasi lapangan (pengamatan visual dan dokumentasi). c) Pembuatan peta, meliputi pembuatan database hasil Global Positioning System dan terakhir pembuatan peta menggunakan perangkat lunak ArcGIS 10.3 .

\section{HASIL DAN PEMBAHASAN}

\section{Analisis Lokasi TPS Ilegal Berdasarkan Volume di Kecamatan Mataram}

Luas wilayah Kecamatan Mataram yaitu $10,76 \mathrm{~km}^{2}$ atau 1.076 ha dengan jumlah penduduk yaitu 87.527 jiwa (Badan Pusat Statistik Kota Mataram, 2018). Pada kecamatan Mataram ditemukan titik-titik lokasi TPS ilegal yang dapat dilihat pada Gambar 2. Titik-titik berwarna merah pada Gambar 2 merupakan TPS ilegal yang berada di seluruh kelurahan di Kecamatan Mataram Kota Mataram. Dari hasil survei yang telah dilakukan, didapatkan 43 titik lokasi TPS ilegal yang tersebar di 9 kelurahan di Kecamatan Mataram yaitu 6 titik TPS ilegal yang berada di Kelurahan Punia, 6 titik berada di Kelurahan Pagesangan Timur, 3 titik di Kelurahan Pagesangan Barat, 6 titik di Kelurahan Pagesangan, 5 titik di Kelurahan Pagutan Barat, 1 titik di Kelurahan Pagutan, 4 titik di Kelurahan Pagutan Timur, 5 titik di Kelurahan Pejanggik, dan 7 titik berada di Kelurahan Mataram Timur. 
Siswandi, E., \& Wahyudin, 2020 Jurnal Sains Informasi Geografi [J SIG], 3(2):65-77, ISSN 2614-1671

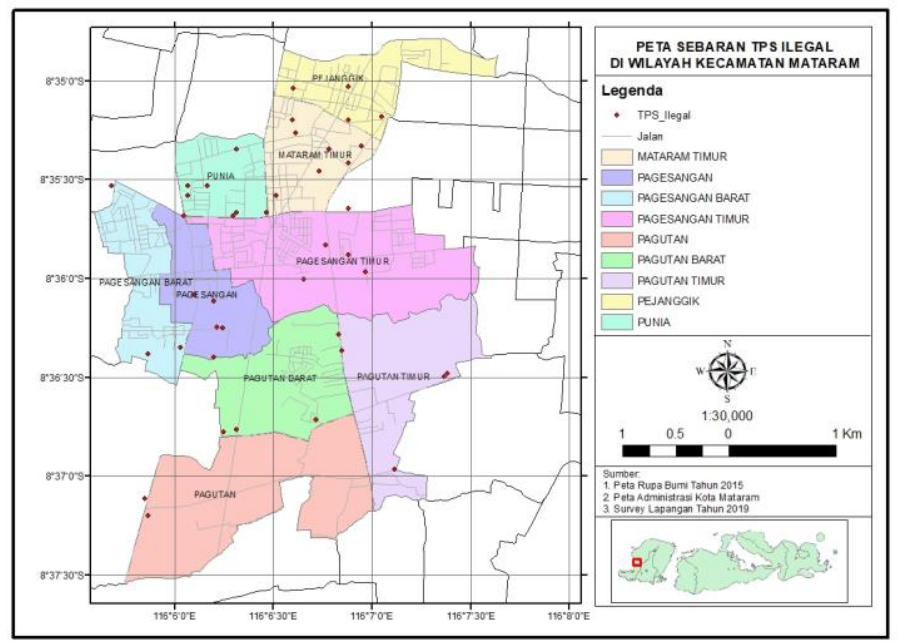

Gambar 2. Peta Lokasi TPS Ilegal Kecamatan Mataram (Sumber: peneliti, 2019)

Titik-titik TPS ilegal tersebut kemudian diklasifikasikan berdasarkan volumenya yaitu TPS ilegal berukuran 0,1-3,5 $\mathrm{m}^{3}, 3,6-12 \mathrm{~m}^{3}$, dan 12,1-37 $\mathrm{m}^{3}$. Adapun titik lokasi TPS ilegal tersebut dapat dilihat pada Tabel 1 berikut.

Tabel 1. Titik Lokasi TPS Ilegal di Kecamatan Mataram

\begin{tabular}{llcccc}
\hline \multirow{2}{*}{ No } & \multirow{2}{*}{ Nama Kelurahan } & \multicolumn{3}{c}{$\begin{array}{c}\text { Jumlah Titik TPS Ilegal Berdasarkan } \\
\text { Volume }\end{array}$} & \multirow{2}{*}{ Total } \\
\cline { 3 - 4 } & & $0,1-3,5 \mathrm{~m}^{3}$ & $3,6-12 \mathrm{~m}^{3}$ & $12,1-37 \mathrm{~m}^{3}$ & \\
\hline 1 & Punia & 4 & 2 & 0 & 6 \\
2 & Pagesangan Timur & 5 & 1 & 0 & 6 \\
3 & Pagesangan Barat & 1 & 2 & 0 & 3 \\
4 & Pagesangan & 6 & 0 & 0 & 6 \\
5 & Pagutan Barat & 4 & 1 & 0 & 5 \\
6 & Pagutan & 1 & 0 & 0 & 1 \\
7 & Pagutan Timur & 3 & 0 & 1 & 4 \\
8 & Pejanggik & 5 & 0 & 0 & 5 \\
9 & Mataram Timur & 7 & 0 & 0 & 7 \\
\hline & Jumlah & 36 & 6 & 1 & $\mathbf{4 3}$ \\
\hline
\end{tabular}

Sumber: Analisis peneliti, 2019

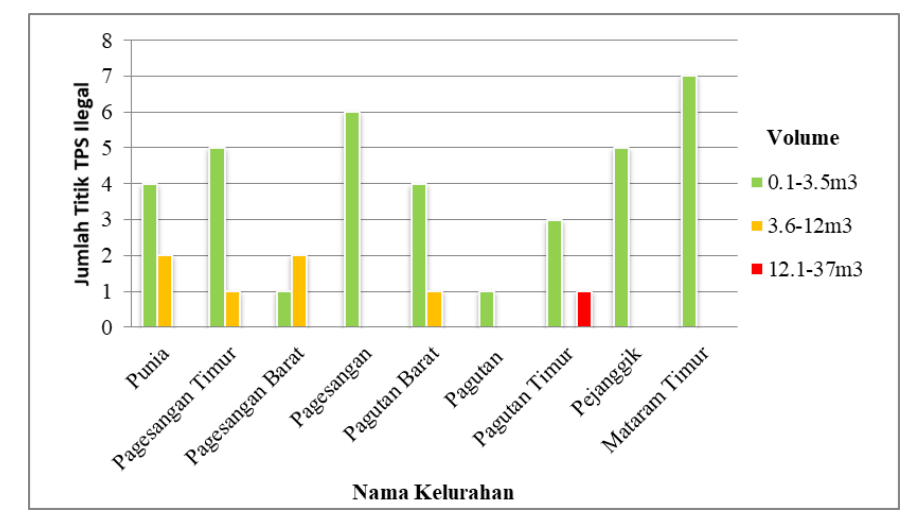

Gambar 3. Histogram Jumlah Titik Lokasi TPS Ilegal Berdasarkan Volume di Kecamatan Mataram (Sumber: Analisis peneliti, 2019)

Setelah melakukan pengkategorian TPS ilegal berdasarkan volume, kemudian dibuatkan peta sebarannya, dapat dilihat pada Gambar 4 berikut. 


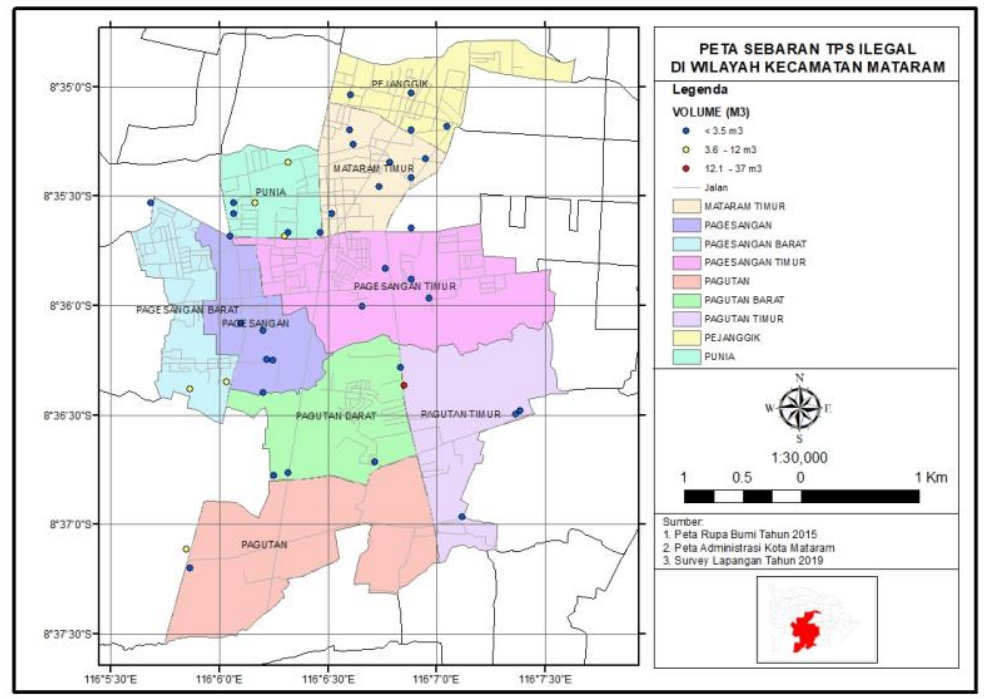

Gambar 4. Peta TPS Ilegal Berdasarkan Volume di Kecamatan Mataram (Sumber: peneliti, 2019)

Titik-titik berwarna biru pada Gambar 5.4 di atas merupakan TPS ilegal yang memiliki volume $0,1-3,5 \mathrm{~m}^{3}$ (kategori kecil), warna kuning adalah TPS ilegal yang memiliki volume 3,6$12 \mathrm{~m}^{3}$ (sedang), dan warna merah adalah TPS ilegal yang memiliki volume 12,1-37 $\mathrm{m}^{3}$ (besar).

\section{Sebaran Titik Lokasi TPS Ilegal di Kecamatan Mataram}

Dari hasil analisis data titik lokasi TPS ilegal di Kecamatan Mataram, didapatkan 43 titik lokasi TPS ilegal yang tersebar di seluruh kelurahan yang ada di Kecamatan Mataram Kota Mataram. Sebaran titik lokasi TPS ilegal di Kecamatan Mataram tidak merata, ada yang lokasinya berdekatan antara titik TPS ilegal yang satu dengan yang lain dan ada juga yang berjauhan.

Kecamatan Mataram terdiri dari 9 kelurahan yang keseluruhannya terdapat TPS ilegal. Titik lokasi TPS ilegal terbanyak terdapat di Kelurahan Mataram Timur yaitu sebanyak 7 titik $(16,28 \%)$. Kemudian untuk Kelurahan Punia, Pagesangan Timur dan Pagesangan, masing-masing terdapat titik lokasi TPS ilegal sebanyak 6 titik $(13,95 \%)$. Kelurahan Pagutan Barat dan Pejanggik masing-masing sebanyak 5 titik (11,63\%). Kelurahan Pagutan Timur sebanyak 4 titik $(9,3 \%)$, Pagesangan Barat sebanyak 3 titik (6,98\%), dan Pagutan sebanyak 1 titik (2,33\%). Persentase sebaran titik lokasi TPS ilegal di Kecamatan Mataram dapat dilihat pada Gambar 5 berikut.

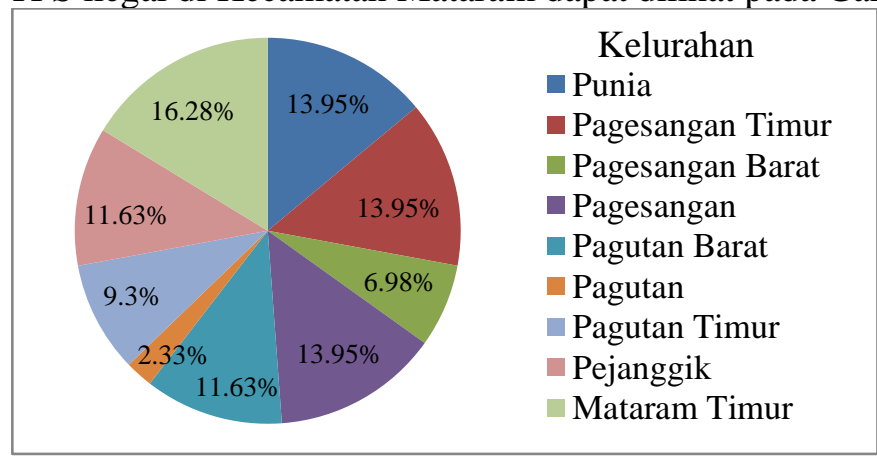

Gambar 5. Persentase Sebaran Titik Lokasi TPS Ilegal di Kecamatan Mataram (Sumber: Analisis peneliti, 2019)

Faktor yang mempengaruhi sebaran titik lokasi TPS ilegal di Kecamatan Mataram yaitu 1) faktor geofisik: jarak titik lokasi TPS dari sungai dan jenis peruntukan lahan, 2) faktor antropogenik: jenis jalan, dan 3) faktor kependudukan: kepadatan penduduk.

\section{Faktor Geofisik}

\section{a) Jarak TPS Ilegal dari Sungai}

Dalam penelitian ini, peneliti tidak hanya berpatokan pada sungai besar saja tetapi juga 
Siswandi, E., \& Wahyudin, 2020 Jurnal Sains Informasi Geografi [J SIG], 3(2):65-77, ISSN 2614-1671

sungai yang kecil yang terdapat di Kecamatan Mataram. Jarak TPS ilegal dari sungai dibagi menjadi 5 variasi jarak yaitu jarak 0-15 m (kategori sangat dekat), 15,01-50 m (dekat), 50,01-250 $\mathrm{m}$ (sedang), 250,01-600 m (jauh), 600,01-1000 m (sangat jauh).

Dari 43 titik lokasi TPS ilegal yang ditemukan di Kecamatan Mataram, didapatkan titik TPS ilegal berjarak 0-15 m dari sungai sebanyak 26 titik (60,46\%), TPS ilegal berjarak 15,01-50 $\mathrm{m}$ dari sungai sebanyak 10 titik (23,26\%), TPS ilegal berjarak 50,01-250 m dari sungai sebanyak 3 titik (6,98\%), TPS ilegal berjarak 250,01-600 m dari sungai sebanyak 2 titik (4,65\%), dan TPS ilegal berjarak 600,01-1000 m dari sungai sebanyak 2 titik (4,65\%). Adapun jumlah titik lokasi TPS ilegal berdasarkan jarak dari sungai dapat dilihat pada Gambar 6 berikut.

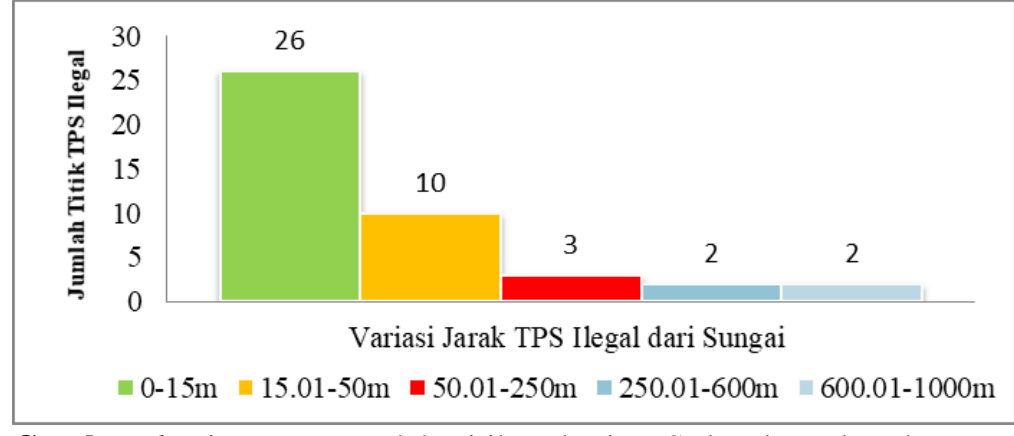

Gambar 6. Histogram Jumlah Titik Lokasi TPS Ilegal Berdasarkan Jarak dari Sungai di Kecamatan Mataram (Sumber: Analisis peneliti, 2019)

Persentase sebaran titik lokasi TPS ilegal berdasarkan jarak dari sungai di Kecamatan Mataram dapat dilihat pada Gambar 7 berikut.

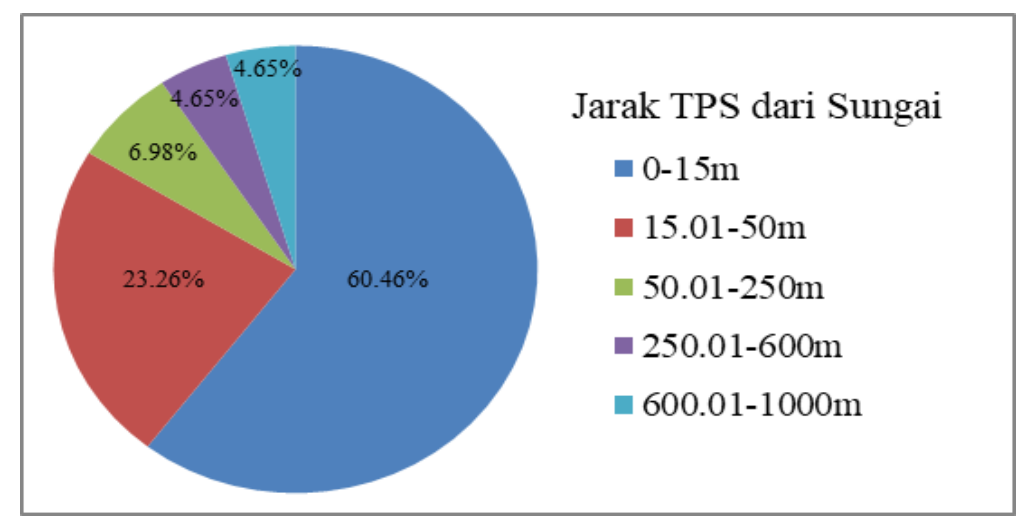

Gambar 7. Persentase Sebaran Titik Lokasi TPS Ilegal Berdasarkan Jarak dari Sungai di Kecamatan Mataram (Sumber:

Analisis peneliti, 2019)

Setelah melakukan analisis terkait jarak TPS ilegal dengan sungai di Kecamatan Mataram, kemudian dibuatkan peta sebarannya. Adapun peta sebaran titik lokasi TPS ilegal berdasarkan jarak dari sungai tersebut, dapat dilihat pada Gambar 8 berikut. 


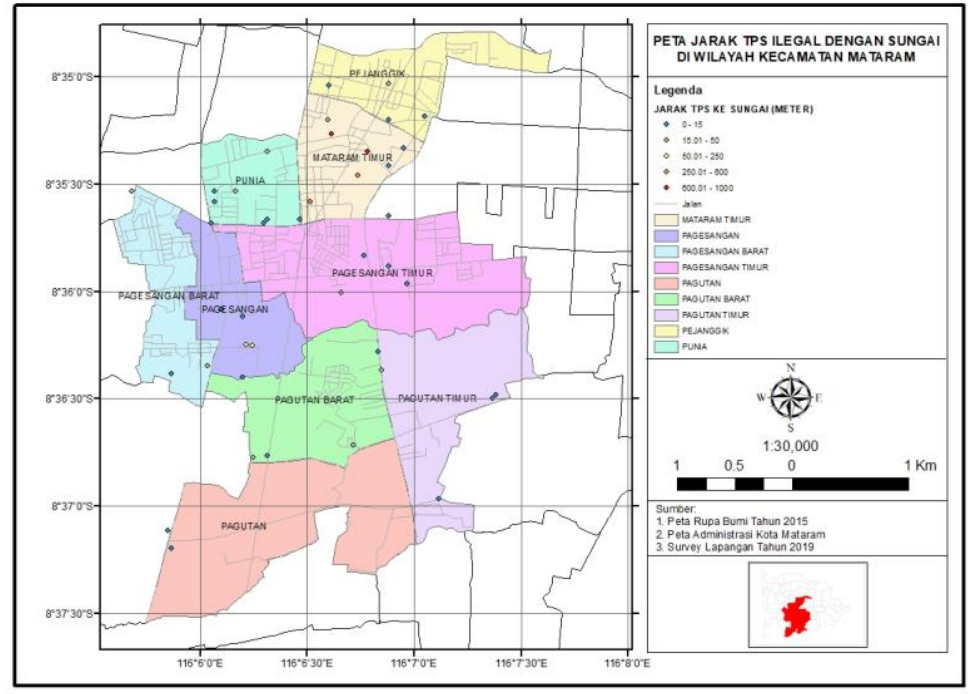

Gambar 8. Peta Jarak Titik Lokasi TPS Ilegal dari Sungai di Kecamatan Mataram (Sumber: Peneliti, 2019)

Keberadaan sungai merupakan salah satu faktor dalam menentukan penyebab munculnya TPS ilegal, karena sampai saat ini sebagian besar sampah yang dihasilkan oleh masyarakat dibuang ke sungai, dan atau dibuang ke tempat kosong seperti pinggir sungai sehingga dapat mengganggu estetika lingkungan (Sidarto, 2010). Hal ini sejalan dengan hasil dalam penelitian ini yaitu dimana semakin dekat jarak titik lokasi TPS ilegal dari sungai, maka akan semakin banyak sebaran titik TPS ilegal, hal ini menunjukkan bahwa jumlah titik lokasi TPS ilegal sangat dipengaruhi oleh faktor jarak dengan sungai. Keadaan ini juga menunjukkan bahwa kesadaran masyarakat di Kecamatan Mataram cukup rendah untuk tidak membuang sampah ke sungai.

\section{b) Jenis Peruntukan Lahan}

Jenis peruntukan lahan merupakan salah satu faktor geofisik yang menentukan munculnya TPS ilegal. Sesuai dengan hasil survei yang didapatkan di lapangan, maka penggolongan jenis peruntukan lahan yang dimaksud dalam penelitian ini yaitu sungai, lahan kosong, sawah, bekas bangunan, dan trotoar jalan. Jumlah titik lokasi TPS ilegal berdasarkan jenis peruntukan lahan dapat dilihat pada Gambar 9 berikut.

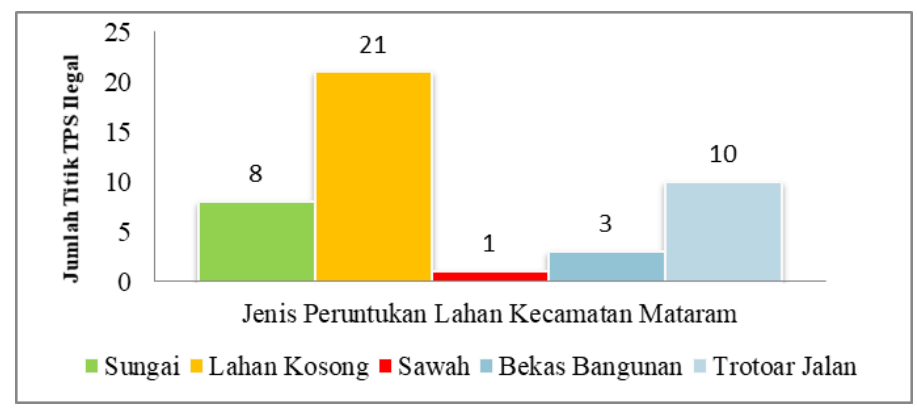

Gambar 9. Histogram Jumlah Titik Lokasi TPS Ilegal Berdasarkan Jenis Peruntukan Lahan di Kecamatan Mataram (Sumber: Analisis peneliti, 2019)

Persentase sebaran titik lokasi TPS ilegal berdasarkan jenis peruntukan lahan di Kecamatan Mataram dapat dilihat pada Gambar 10 berikut. 


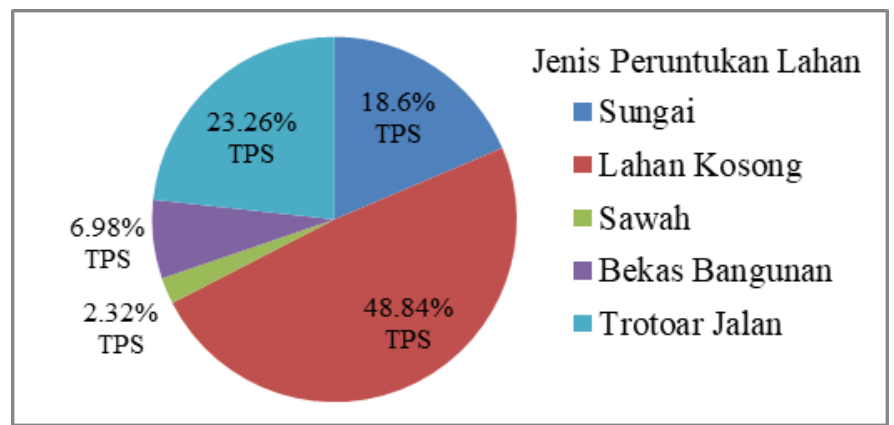

Gambar 10. Persentase Sebaran Titik Lokasi TPS Ilegal

Berdasarkan Jenis Peruntukan Lahan di

Kecamatan Mataram (Sumber: Analisis peneliti,

2019)

Berdasarkan pengaruh jenis peruntukan lahan terhadap keberadaan TPS ilegal di Kecamatan Mataram, ditemukan 8 titik $(18,6 \%)$ dari 43 titik lokasi TPS ilegal berada di sungai yang tersebar di 4 kelurahan, yaitu 1 titik masing-masing di Kelurahan Pagesangan Timur dan Pagesangan, serta 3 titik masing-masing di Kelurahan Pejanggik dan Mataram Timur.

Titik lokasi TPS ilegal yang berada di lahan kosong ditemukan sebanyak 21 titik $(48,84 \%)$ tersebar di 8 kelurahan, yaitu 3 titik masing-masing di Kelurahan Punia dan Pagesangan Timur, 2 titik masing-masing di Kelurahan Pagesangan Barat dan Pagutan Timur, 4 titik di Kelurahan Pagesangan, 5 titik di Kelurahan Pagutan Barat, dan 1 titik masing-masing di Kelurahan Pejanggik dan Mataram Timur.

Titik lokasi TPS ilegal yang berada di persawahan sebanyak 1 titik $(2,32 \%)$ yaitu di Kelurahan Pagesangan Timur. Kemudian, titik lokasi TPS ilegal yang berada di sekitar bekas bangunan ditemukan sebanyak 3 titik $(6,98 \%)$ tersebar di 3 kelurahan, yaitu masing-masing 1 titik di Kelurahan Pagutan, Pagutan Timur, dan Mataram timur. Titik lokasi TPS ilegal yang berada di trotoar jalan ditemukan sebanyak 10 titik $(23,26 \%)$ tersebar di 7 kelurahan, yaitu 3 titik di Kelurahan Punia, masing-masing 1 titik di Kelurahan Pagesangan Timur, Pagesangan Barat, Pagesangan, Pagutan Timur, dan Pejanggik, serta 2 titik di Kelurahan Mataram Timur.

Penggunaan lahan di Kecamatan Mataram sebagian besar digunakan sebagai lahan bukan pertanian yaitu berupa pekarangan seluas 932,34 ha atau 86,65\% (BPS Kota Mataram, 2018). Keberadaan pekarangan yang lebih luas dari lahan pertanian menyebabkan banyak lahan kosong yang berada di sekitar perumahan masyarakat. Tersedianya lahan kosong mendorong masyarakat untuk membuang sampah di lokasi tersebut. Hal ini terlihat dari tingginya persentase jumlah titik TPS ilegal yang berada di tanah kosong yaitu sebesar 48,84\% atau 21 titik dari 43 titik lokasi TPS ilegal yang ada di Kecamatan Mataram. Jika dilihat dari sebaran di setiap kelurahan, terlihat bahwa 8 dari 9 kelurahan yang ada di Kecamatan Mataram terdapat titik lokasi TPS ilegal yang berada di lahan kosong. Data ini menunjukkan bahwa semakin banyak lahan kosong di suatu wilayah, maka semakin besar pula potensi terbentuknya TPS ilegal di Kecamatan Mataram.

Keberadaan trotoar jalan juga berpengaruh terhadap timbulnya TPS ilegal. Hasil penelitian ini menunjukkan bahwa 23,26\% atau 10 titik dari 43 titik TPS ilegal berada di trotoar jalan yang ada di Kecamatan Mataram. Jika dilihat dari sebaran di setiap kelurahan, terlihat bahwa 7 dari 9 kelurahan yang ada di Kecamatan Mataram terdapat titik lokasi TPS ilegal yang berada di trotoar jalan. Data ini menunjukkan bahwa keberadaan trotoar jalan juga berpotensi terhadap terbentuknya TPS ilegal di Kecamatan Mataram.

Di samping keberadaan tanah kosong dan trotoar jalan, keberadaan sungai juga berpotensi terhadap timbulnya TPS ilegal. Hasil penelitian ini menunjukkan bahwa 18,6\% atau 8 titik dari 43 titik TPS ilegal berada di sungai yang ada di Kecamatan Mataram. Jika dilihat dari sebaran di setiap kelurahan, terlihat bahwa 4 dari 9 kelurahan yang ada di Kecamatan Mataram terdapat titik lokasi TPS ilegal yang berada di sungai. Data ini menunjukkan bahwa keberadaan sungai juga berpotensi terhadap terbentuknya TPS ilegal.

Berdasarkan uraian di atas, terlihat bahwa keberadaan lahan kosong merupakan penyebab terbesar timbulnya TPS ilegal di Kecamatan Mataram. Hal ini sejalan dengan definisi penampungan ilegal (US EPA Region 5, 1998: 4) yaitu penampungan ilegal merupakan penampungan sampah di dalam wilayah yang tidak terpakai atau lahan kosong termasuk 
bangunan yang sudah ditinggalkan, di lahan kosong milik publik atau pribadi, dan jalan raya, serta daerah di sepanjang jalan pedesaan juga rentan menjadi lokasi TPS ilegal.

\section{Faktor Antropogenik}

Faktor antropogenik yang mempengaruhi sebaran titik lokasi TPS ilegal di Kecamatan Mataram salah satunya yaitu jenis jalan yang berada di dekat TPS. Jenis-jenis jalan dalam penelitian ini didasarkan pada Peraturan Pemerintah Republik Indonesia Nomor 34 Tahun 2006 tentang Jalan. Berdasarkan sifat dan pergerakan pada lalu lintas dan angkutan jalan, fungsi jalan dibedakan atas arteri, kolektor, lokal, dan lingkungan. Jalan arteri berfungsi menghubungkan antarpusat kegiatan nasional atau antara pusat kegiatan nasional dengan pusat kegiatan wilayah. Jalan kolektor berfungsi menghubungkan antara pusat kegiatan nasional dengan pusat kegiatan lokal, antarpusat kegiatan wilayah, atau antara pusat kegiatan wilayah dengan pusat kegiatan lokal. Jalan lokal berfungsi menghubungkan pusat kegiatan nasional dengan pusat kegiatan lingkungan, pusat kegiatan wilayah dengan pusat kegiatan lingkungan, antarpusat kegiatan lokal, atau pusat kegiatan lokal dengan pusat kegiatan lingkungan, serta antarpusat kegiatan lingkungan. Jalan lingkungan berfungsi menghubungkan antarpusat kegiatan di dalam kawasan pedesaan dan jalan di dalam lingkungan kawasan pedesaan.

Berdasarkan jenis jalan yang berada dekat dengan titik lokasi TPS ilegal di Kecamatan Mataram, ditemukan 4 titik lokasi TPS ilegal yang berada dekat dengan jalan arteri, 5 titik berada dekat dengan jalan kolektor, 9 titik berada dekat dengan jalan lokal, dan 25 titik berada dekat dengan jalan lingkungan. Adapun jumlah titik lokasi TPS ilegal berdasarkan jenis jalan terdekat, dapat dilihat pada Gambar 11 berikut.

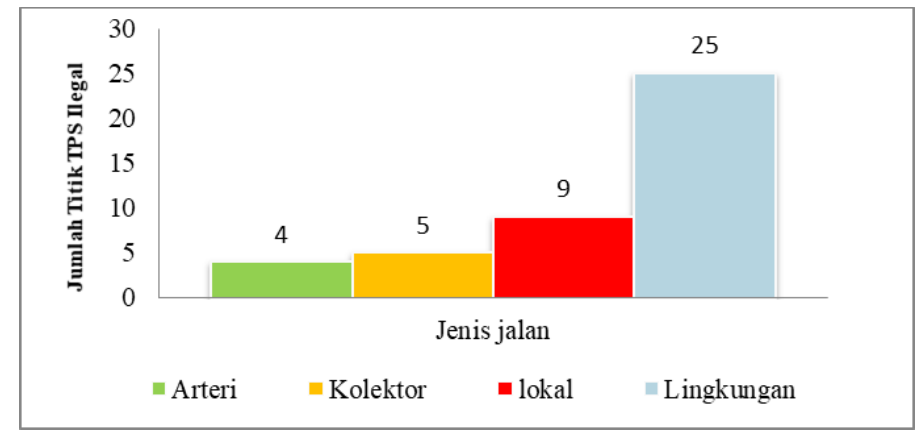

Gambar 11. Histogram Jumlah Titik Lokasi TPS Ilegal

Berdasarkan Jenis Jalan di Kecamatan Mataram

(Sumber: Analisis peneliti, 2019)

Persentase sebaran titik lokasi TPS ilegal berdasarkan jenis jalan di Kecamatan Mataram dapat dilihat pada Gambar 12 berikut.

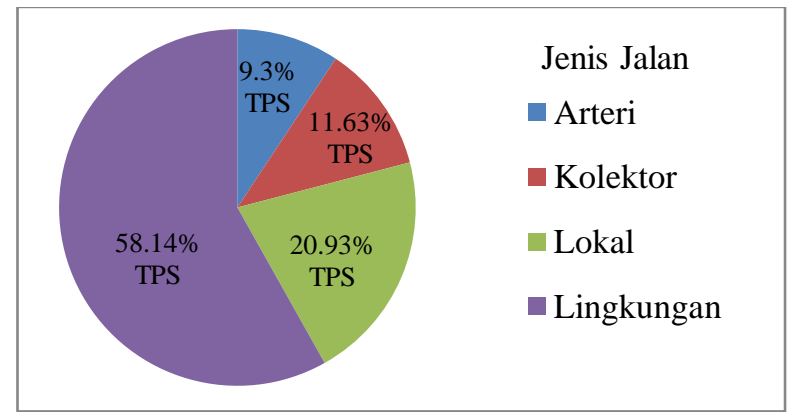

Gambar 12. Persentase Sebaran Titik Lokasi TPS Ilegal Berdasarkan Jenis Jalan di Kecamatan Mataram (Sumber: Analisis peneliti, 2019)

Penelitian ini dilakukan dengan menelusuri seluruh jalan yang ada di Kecamatan Mataram dari jalan arteri sampai ke jalan lingkungan yang bersentuhan langsung ke rumah-rumah warga. Dari data hasil survei langsung ke tiap-tiap titik lokasi TPS ilegal, terlihat bahwa akses jalan mempengaruhi timbulnya titik lokasi TPS ilegal di Kecamatan Mataram, hal ini sejalan dengan 
penelitian (Tasaki, dkk. 2007) menyatakan bahwa jarak dari jalan juga berdampak pada penampungan ilegal, karena faktor ini mempengaruhi aksesibilitas ke tempat penampungan.

Data hasil survei yang diperoleh menunjukkan bahwa sebagian besar titik lokasi TPS ilegal berada atau berdekatan dengan jalan lingkungan, berjarak kurang dari $100 \mathrm{~m}$. Dari 43 titik lokasi TPS ilegal yang ada di Kecamatan Mataram terdapat sebanyak 25 titik $(58,14 \%)$ berada dekat dengan jalan lingkungan. Banyaknya titik lokasi TPS ilegal yang berada dekat dengan jalan lingkungan dikarenakan jenis jalan yang mendominasi di Kecamatan Mataram adalah jalan lingkungan. Dengan banyaknya jalan lingkungan, memungkin warga yang kesehariannya melewati jalan tersebut terdorong untuk membuang sampah di lokasi atau dekat jalan tersebut. Hal inilah yang memicu timbulnya titik lokasi TPS ilegal yang berada di Kecamatan Mataram. Lokasi TPS ilegal yang berada di dekat jalan ataupun berada di bahu jalan akan memudahkan siapapun untuk membuang sampah di lokasi tersebut, sehingga pengguna TPS ilegal ini bisa saja tidak hanya berasal dari masyarakat setempat akan tetapi juga bisa dari masyarakat lain yang melintasi jalan tersebut. Selanjutnya, ditemukan 9 titik (20,93\%) lokasi TPS ilegal berada dekat dengan jalan lokal. Sama halnya dengan jalan lingkungan, jalan lokal ini juga tergolong cukup rentan untuk memicu timbulnya TPS ilegal.

Selain itu, ditemukan 4 titik $(9,3 \%)$ lokasi TPS ilegal yang berada dekat dengan jalan arteri dan 5 titik $(11,63 \%)$ berada dekat dengan jalan kolektor. Jumlah titik lokasi TPS ilegal yang berada dekat dengan jalan arteri dan jalan kolektor lebih sedikit jika dibandingkan dengan TPS ilegal yang berada dekat dengan jalan lingkungan dan jalan lokal. Hal ini disebabkan pengangkutan yang dilakukan oleh petugas hanya fokus pada jalan-jalan utama/arteri dan jalan kolektor saja sehingga tidak memasuki jalan lainnya (jalan lingkungan dan jalan lokal), karena penempatan TPS legal juga memperhitungkan akses jalan yang akan dilalui oleh kendaraan pengangkut sampah untuk mengangkut sampah menuju TPA (Nadiasa, dkk. 2009).

\section{Faktor Kependudukan}

Faktor kependudukan yang mempengaruhi sebaran titik lokasi TPS ilegal di Kecamatan Mataram yang dimaksud dalam penelitian ini yaitu kepadatan penduduk. Faktor kepadatan penduduk memiliki pengaruh terhadap sebaran lokasi TPS ilegal, karena laju timbulan sampah yang dihasilkan suatu daerah semakin lama semakin meningkat dengan bertambahnya jumlah penduduk di daerah tersebut (Nadiasa, dkk. 2009), hal ini juga akan menyebabkan semakin meningkatnya kebutuhan akan tempat penampungan sampah. Dalam penelitian ini, klasifikasi tingkat kepadatan penduduk menggunakan SNI 03-1733-2004 tentang Tata Cara Perencanaan Lingkungan Perumahan di Perkotaan. Adapun SNI yang digunakan tersebut dapat dilihat pada Tabel 2 berikut.

Tabel 2. Klasifikasi Kepadatan Penduduk

\begin{tabular}{ccc}
\hline No & Kepadatan Penduduk (jiwa/ha) & Kategori \\
\hline 1 & $<150$ & Rendah \\
2 & $151-200$ & Sedang \\
3 & $201-400$ & Tinggi \\
4 & $>400$ & Sangat Padat \\
\hline
\end{tabular}

Sumber: SNI 03-1733-2004

Data kepadatan penduduk tiap kelurahan di Kecamatan Mataram dapat dilihat pada Tabel 3 berikut.

Tabel 3. Kepadatan Penduduk di Kecamatan Mataram Tahun2017

\begin{tabular}{llccccc}
\hline No & Kelurahan & $\begin{array}{c}\text { Jumlah Titik } \\
\text { Lokasi TPS } \\
\text { Ilegal }\end{array}$ & $\begin{array}{c}\text { Jumlah } \\
\text { Penduduk } \\
\text { (jiwa) }\end{array}$ & $\begin{array}{c}\text { Luas } \\
\text { Wilayah } \\
\text { (ha) }\end{array}$ & $\begin{array}{c}\text { Kepadatan } \\
\text { Penduduk } \\
\text { (jiwa/ha) }\end{array}$ & Kategori \\
\hline 1 & Punia & 6 & 7559 & 88 & 85.90 & Rendah \\
2 & $\begin{array}{l}\text { Pagesangan } \\
\text { Timur }\end{array}$ & 6 & 12636 & 110 & 114.87 & Rendah \\
3 & $\begin{array}{l}\text { Pagesangan } \\
\text { Barat }\end{array}$ & 3 & 11445 & 75 & 152.60 & Sedang \\
4 & Pagesangan & 6 & 10027 & 196 & 51.16 & Rendah
\end{tabular}


Siswandi, E., \& Wahyudin, 2020 Jurnal Sains Informasi Geografi [J SIG], 3(2):65-77, ISSN 2614-1671

\begin{tabular}{|c|c|c|c|c|c|c|}
\hline 5 & Pagutan Barat & 5 & 12158 & 91 & 133.60 & Rendah \\
\hline 6 & Pagutan & 1 & 10890 & 186 & 58.55 & Rendah \\
\hline 7 & Pagutan Timur & 4 & 7034 & 103 & 68.29 & Rendah \\
\hline 8 & Pejanggik & 5 & 9349 & 103 & 90.77 & Rendah \\
\hline 9 & $\begin{array}{l}\text { Mataram } \\
\text { Timur }\end{array}$ & 7 & 6429 & 124 & 51.85 & Rendah \\
\hline & Jumlah & 43 & 87527 & 1076 & 81.34 & \\
\hline
\end{tabular}

Sumber: Analisis peneliti, 2019

Berdasarkan faktor kependudukan di Kecamatan Mataram, terlihat bahwa kepadatan penduduk tertinggi berada di Kelurahan Pagesangan Barat dengan kepadatan 152,60 jiwa/ha (kategori sedang) dengan jumlah titik TPS ilegal yang sedikit jika dibandingkan dengan kelurahan yang lain yaitu sebanyak 3 titik. Hal ini disebabkan karena Kelurahan Pagesangan Barat memiliki luas wilayah yang paling kecil dibandingkan kelurahan lain di Kecamatan Mataram yaitu 75ha dan jumlah penduduknya sebesar 11.445 jiwa. Dengan jumlah penduduk yang padat disertai wilayah yang kecil, menyebabkan sedikit tersedianya lahan kosong yang rentan digunakan masyarakat sebagai tempat penampungan sampah ilegal. Inilah yang menyebabkan sedikitnya titik lokasi TPS ilegal di Kelurahan Pagesangan Barat.

Kepadatan penduduk terendah berada di Kelurahan Pagesangan yaitu 51,16 jiwa/ha (kategori rendah) dengan jumlah titik TPS ilegal yang cukup banyak jika dibandingkan dengan kelurahan yang lain yaitu 6 titik. Kelurahan Pagesangan memiliki luas wilayah yang paling besar dibandingkan kelurahan lain di Kecamatan Mataram yaitu 196 ha dan jumlah penduduknya sebesar 10.027 jiwa. Dengan kepadatan penduduk yang rendah disertai wilayah yang luas, menyebabkan banyak tersedianya lahan kosong yang rentan digunakan masyarakat sebagai tempat penampungan sampah ilegal. Inilah yang menjadi penyebab banyaknya titik lokasi TPS ilegal di Kelurahan Pagesangan.

Hubungan antara kepadatan penduduk dengan banyaknya jumlah titik lokasi TPS ilegal di Kecamatan Mataram setelah diurutkan terlihat tidak stabil. Banyaknya titik lokasi TPS ilegal pada 9 Kelurahan yang ada di Kecamatan Mataram tidak hanya terpengaruh oleh kepadatan penduduk yang ada di wilayah tersebut saja tetapi bisa saja dari luar, hal ini seperti yang dapat dilihat pada Gambar 13 berikut.

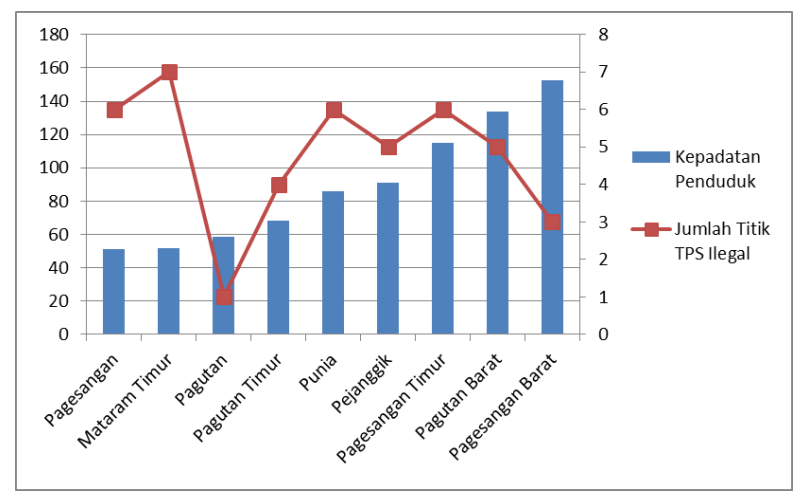

Gambar 13. Histogram Jumlah Titik Lokasi TPS Ilegal

Berdasarkan Kepadatan Penduduk di

Kecamatan Mataram (Sumber: Analisis peneliti, 2019)

Klasifikasi kepadatan penduduk berdasarkan SNI 03-1733-2004 di Kecamatan Mataram memiliki tingkat kepadatan yang rendah yaitu di bawah $150 \mathrm{jiwa} / \mathrm{ha}$. Kepadatan penduduk tidak dapat begitu saja dijadikan faktor utama terkait pengaruhnya terhadap jumlah titik lokasi TPS ilegal di Kecamatan Mataram, hal ini dikarenakan penduduk yang tidak tetap dan adanya penduduk pendatang yang tidak tercatat di Kecamatan Mataram. Tidak hanya itu, faktor jenis jalan juga memungkinkan pengguna TPS ilegal tidak berasal wilayah tersebut saja sehingga faktor kependudukan tidak bisa dijadikan faktor utama penyebab timbulnya TPS ilegal di Kecamatan Mataram. 


\section{KESIMPULAN}

Penyebaran lokasi dari 43 TPS Ilegal hampir merata di 9 kelurahan di Kecamatan Mataram. Karakteristik TPS Ilegal ditinjau dari volume, jarak dengan sungai, jenis penggunaan lahan, jenis jalan yang ditempati, dan kepadatan penduduk. Volume TPS Ilegal terbesar yang diperoleh yaitu sebesar $36 \mathrm{~m}^{3}$, lokasi TPS Ilegal berjarak kurang dari $15 \mathrm{~m}$ dari sungai sebesar 60,46\% dan berada di jalan lingkungan yakni sebesar 58,14\%. Sedangkan kepadatan penduduk tidak dapat dijadikan faktor utama terkait pengaruhnya terhadap jumlah titik TPS ilegal di Kecamatan Mataram. Dengan demikian keberadaan TPS Ilegal tersebut sangat berpotensi mencemari lingkungan karena berada dekat dengan sungai dan berada di lingkungan permukiman.

\section{UCAPAN TERIMA KASIH}

Penulis mengucapkan terima kasih kepada semua pihak terkait antara lain, Direktorat Riset dan Pengabdian Masyarakat (DRPM) yang telah memberikan dana hibah penelitian Doses Pemula (PDP) Pendanaan Tahun 2019 dengan nomor kontrak penelitian DRPM dengan STTL Mataram, No. 0861/L8/KM/2019. Penulis juga mengucapkan terima kasih kepada Kepala Balitbang Kota Mataram, H. Lalu Johari yang telah memberikan dan mengeluarkan surat izin penelitian dengan nomor surat: 070/340/Balitbang-KT/V/2019.

\section{DAFTAR PUSTAKA}

Anonim. 2004. Tata Cara Perencanaan Lingkungan Perumahan di Perkotaan. SNI 03-17332004. Badan Standarisasi Nasional. Jakarta.

Anonim. 2006. Peraturan Pemerintah Republik Indonesia Nomor 34 Tahun 2006 Tentang Jalan. Republik Indonesia. Jakarta.

Anonim. 2008. Undang-Undang Republik Indonesia Nomor 18 Tahun 2008 Tentang Pengelolaan Sampah. Republik Indonesia. Jakarta.

Anonim. 2008. Peraturan Daerah Kota Mataram Nomor 10 Tahun 2008 Tentang Pengelolaan Sampah. Pemerintah Kota Mataram. Mataram.

Anonim. 2012. Peraturan Pemerintah Republik Indonesia Nomor 81 Tahun 2012 Tentang Pengelolaan Sampah Rumah Tangga dan Sampah Sejenis Sampah Rumah Tangga. Republik Indonesia. Jakarta.

Anonim. 2018. Kecamatan Mataram dalam Angka Tahun 2018. Badan Pusat Statistik. Kota Mataram

Eshet, T., Baron, M.G., Shechter, S., dan Ayalon, O. 2017. Measuring Externalities of Waste Transfer Station in Israel Using Hedonic Pricing. Waste Management. 27, 614-625.

Indarto. 2010. Dasar-Dasar Sistem Informasi Geografis. Jawa Timur: Jember University Press.

Jatmiko. 2011. Pengembangan Peta Tiga Dimensi Interaktif Gedung Teknik Elektro Institut Teknologi Sepuluh Nopember Surabaya Menggunakan Unreal Engine. Undergraduate Thesis, Institut Teknologi Sepuluh Nopember, Surabaya

Nadiasa, M., Sudarsana, D.K., Yasmara, I.N. 2009. Manajemen Pengangkutan Sampah di Kota Amlapura. Bali. Jurnal Ilmiah Teknik Sipil, 13(2), 120-135.

Ni Ketut Pradani Gayatri S, Githa, Dwi Putra, I. P. A. (2018). Sistem Informasi Geografis Rekomendasi Objek Wisata Bali Menggunakan Metode TOPSIS. Jurnal Merpati, 6(2), 96-107. Retrieved from https://ojs.unud.ac.id/index.php/merpati/article/view/45441

Riyanto. 2010. Sistem Informasi Geografis Berbasis Mobile. Gava Media: Yogyakarta.

Rochman, F., Hardjono, I., dan Anggoro, A. 2012. Analisis Kesesuaian Lahan untuk Penentuan Tempat Pembuangan Akhir (TPA) di Kecamatan Pleret Kabupaten Bantul. Yogyakarta: Fakultas Geografi Universitas Muhammadiyah Yogyakarta.

Sidarto. 2010. Analisis Usaha Proses Pengelolaan Sampah Rumah Tangga dengan Pendekatan Cost and Benefit Ratio Guna Menunjang Kebersihan Lingkungan. Jurnal Teknologi, 3(2), 161-168.

Supriadi dan Nasution. 2007. Sistem Informasi Geografis. Medan: USU-Press.

Tasaki, T., Kawahata, T., Osako, M., Matsui, Y., Takagishi, S., Morita, A., dan Akishima, S. 2007. A GIS-Based Zoning of Illegal Dumping Potential for Efficient Surveillance. Waste Management, 27:256-267. 
Siswandi, E., \& Wahyudin, 2020 Jurnal Sains Informasi Geografi [J SIG], 3(2):65-77, ISSN 2614-1671

US EPA. 1998. Illegal Dumping Prevention Guidebook EPA905-B-97-001. Chichago, Illinois: US EPA Region 5. 